\title{
Laser Doppler Assessment of Microcirculation of Apical Periodontitis before Nonsurgical and during Surgical Laser Treatment
}

\author{
Bogdan Krastev, Ivan Filipov \\ Department of Operative Dentistry and Endodontics, Faculty of Dental Medicine, Medical University of Plovdiv, Plovdiv, Bulgaria
}

Corresponding author: Bogdan Krastev, Department of Operative Dentistry and Endodontics, Faculty of Dental Medicine, Medical University of Plovdiv, 3 Hristo Botev Blvd., 4000 Plovdiv, Bulgaria; E-mail: drbkrastev@gmail.com; Tel.: +359 897988845

Received: 10 Nov 2019 Accepted: 11 Feb 2020 Published: 30 Sep 2020

Citation: Krastev B, Filipov I. Laser Doppler assessment of microcirculation of apical periodontitis before nonsurgical and during surgical laser treatment. Folia Med (Plovdiv) 2020;62(3):619-25. doi: 10.3897/folmed.62.e48340.

\begin{abstract}
Introduction: Laser doppler flowmetry is a non-invasive method of measuring microcirculatory blood flow in tissue. Using laser doppler flowmetry Moor VMS-LDF1-HP and CP1T-HP probe combined with Moor VMS-PC software to evaluate the state of the periapical lesion (cyst) before nonsurgical endodontic treatment with bioceramics (Well Root $\mathrm{SP}^{\mathrm{mix}}$ ) and compare it to a healthy vital tooth of the same type with no periapical lesions. Later the bony crypt of the cyst was evaluated with Moor VMSLDF1-HP and VP7BS-HP probe during periapical surgery after the cyst was ablated with Er: YAG laser Lite Touch ${ }^{\text {ix }}$ (Sineron, Israel) and retrogradely obturated with TheraCal LC ${ }^{\circ}$. Then the cyst received a bioceramic bone graft. To our knowledge, this is the first time laser doppler has been used during periapical surgery to evaluate tissue perfusion. Lesion type was confirmed with a histological examination after surgery.
\end{abstract}

Aim: Evaluate tissue perfusion of a periapical lesion before nonsurgical treatment and during surgical endodontic treatment with Er:YAG laser with the help of laser doppler flowmeter.

Results: Laser doppler flowmetry shows that the cystic tooth has a decreased blood flow, decreased concentration, direct current, speed, and lower temperature compared to a healthy tooth of the same type. During periapical surgery, the direct laser blood flow evaluation of the surgical crypt shows different values of the flux, speed, direct current, concentration, and temperature, which could be attributed to the mechanical trauma, adrenaline in the local anaesthetic or laser irradiation of tissues.

Conclusions: Laser doppler flowmetry is a valuable method to perform tissue evaluation before, during and after treatment. It allows us to follow up the healing and pathological dynamics of microcirculatory tissue changes as well as evaluate and compare different methods and materials for treatment of apical periodontitis.

\section{Keywords}

cyst, Er:YAG, laser doppler flowmetry, laser, perfusion

\section{INTRODUCTION}

Apical periodontitis can be caused by a variety of factors but infection is the most common cause. ${ }^{1}$ Most periapical cysts are the result of apical periodontitis. ${ }^{2}$ A radicular cyst is usually formed by inflammatory proliferation of the epithelial cell rests of Malassez. Cysts depending on their rela- tion to the root canal can be categorized as either pocket cysts or true cysts. Radicular cysts cannot be diagnosed clinically using conventional radiographic or even cone beam computed tomographic images. Definitively they can be diagnosed only by histological examination of biopsy specimens. They have a sclerotic border and their growth in size is exerting pressure over bone resorbing it, thus decreasing

Copyright by authors. This is an open access article distributed under the terms of the Creative Commons Attribution License (CC-BY 4.0), 
its microcirculation. Microcirculation can be assessed by laser doppler flowmetry monitoring or imaging devices. ${ }^{3}$ Because radicular cysts are caused by root canal infection, it is believed that they can be treated by conventional root canal therapy. Not all authors agree and some recommend radical treatment e.g. endodontic surgery. ${ }^{4}$

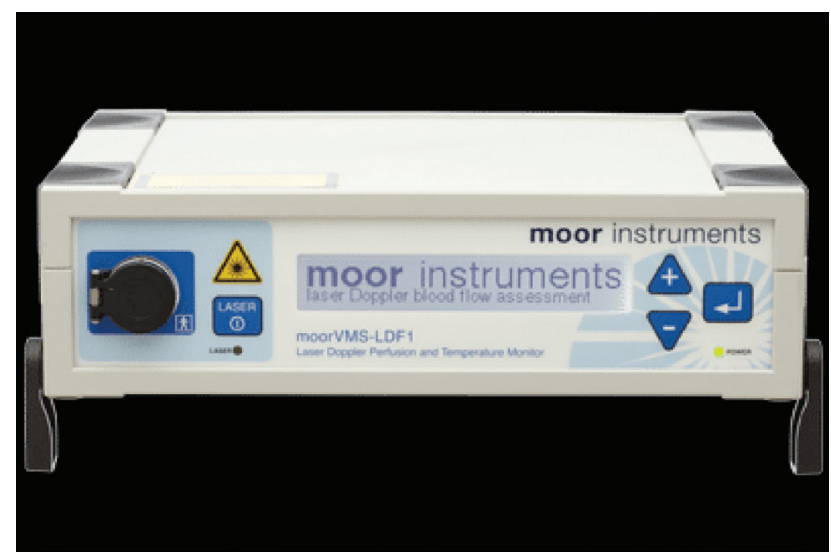

Figure 1. High power laser doppler flowmeter monitor Moor VMS-LDF1-HP.

\section{CASE REPORT}

A 30-year-old male, a medical student was diagnosed with a periapical lesion on tooth 13 (Figs 2, 3) via 3D cone beam computed tomography (CBCT) and referred to the Department of Operative Dentistry and Endodontics. Tooth 13 was asymptomatic with no restorations and no previous root canal treatment. The tooth had a previous history of trauma. The lesion on tooth 13 was found accidentally by CBCT due to previous implant placement in the region of tooth 12 . Non-surgical root canal treatment was performed on tooth 13 with a rubber dam. Working length was $28 \mathrm{~mm}$. The final master apical file was Pro Taper Universal F3 ISO 30, taper 09. Irrigation protocol was $\mathrm{NaOCl} 5.25 \%$ and EDTA $17 \%$. Final irrigation solution was $\mathrm{NaCl} 0.9 \%$. The root canal was dried with paper points and obturated with Well Root ST (calcium silicate, Vericom Co Ltd, Republic of Korea) bio- ceramic sealer and gutta-percha with continuous wave condensation technique performed with Elements Free obturation system (Kerr Corporation, CA, USA), 150 degrees $C^{\circ}$ setting and Buchanan Hand pluggers. After the nonsurgical root canal treatment a CBCT (Fig. 4) and a periapical X-ray (Fig. 6) were performed to evaluate the $3 D$ root canal obturation. The lesion was $7 \times 8$ (height $\times$ width) $7 \mathrm{~mm}$ buccolingually, encroaching into the right sinus cavity. Since the first CBCT, the lesion had resorbed the buccal cortical bone. The nonsurgical microcirculation measurement of the periapical lesion was done prior to the root canal treatment with laser doppler flowmeter (LDF) monitor Moor VMS LDF1-HP (Fig. 1). Tooth 23 was vital responding to cold stimulus and with no restorations. It served as a healthy control site for the test. The skin probe CP1T-HP (Fig. 5) was placed for 1 minute in the apical area of teeth 13,23 (buccal fold) over the free mucosa, touching it. The target zone was over the conjectural area of the periapical lesion (tooth 13) - root apex (tooth 23). Probe area was $5 \mathrm{~cm}^{2}$ which delivers maximum power density of $0.03 \mathrm{~W} / \mathrm{cm}^{2}$. It was used at a $0.5 \mathrm{~s}$ pulse and $15 \mathrm{~Hz}$ which delivers $0.00 \mathrm{~W}$ or peak power of $0.01 \mathrm{~W} / \mathrm{cm}^{2}$. The graphical and numerical representation of the readings is shown in Fig. 7 and Table 1. The peaks in Fig. 7 are artefacts of Flux (perfusion) and CONC (concentration of erythrocytes) which are represented by the black and light red lines and correspond to the min and max values in Table 1. The vertical axis represents the values of Flux (perfusion units), CONC (arbitrary units), Speed (of erythrocytes), DC (direct current), Temp $\left({ }^{\circ} \mathrm{C}\right)$ and the horizontal axis represents

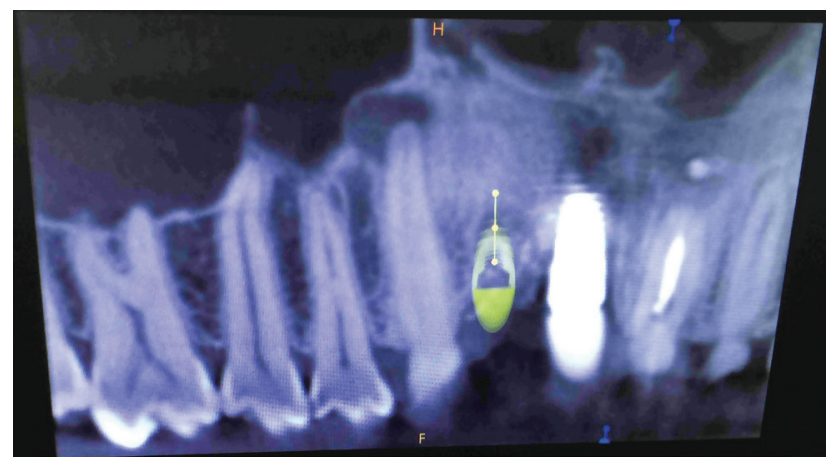

Figure 2. CBCT, sagittal view of tooth 13 before root canal treatment.

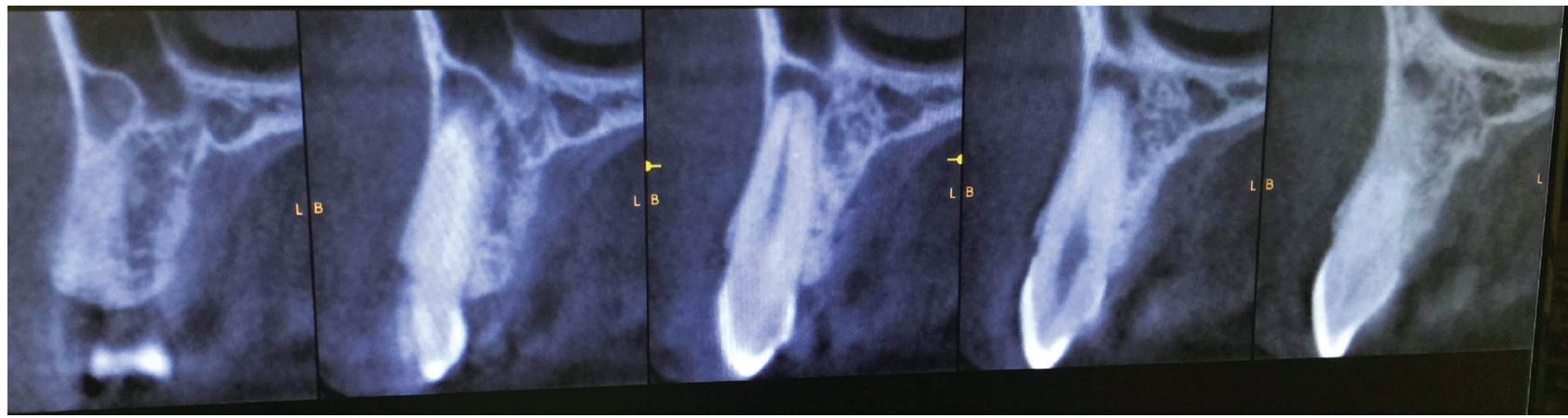

Figure 3. СВСТ, axial view of tooth 13 before root canal treatment. 


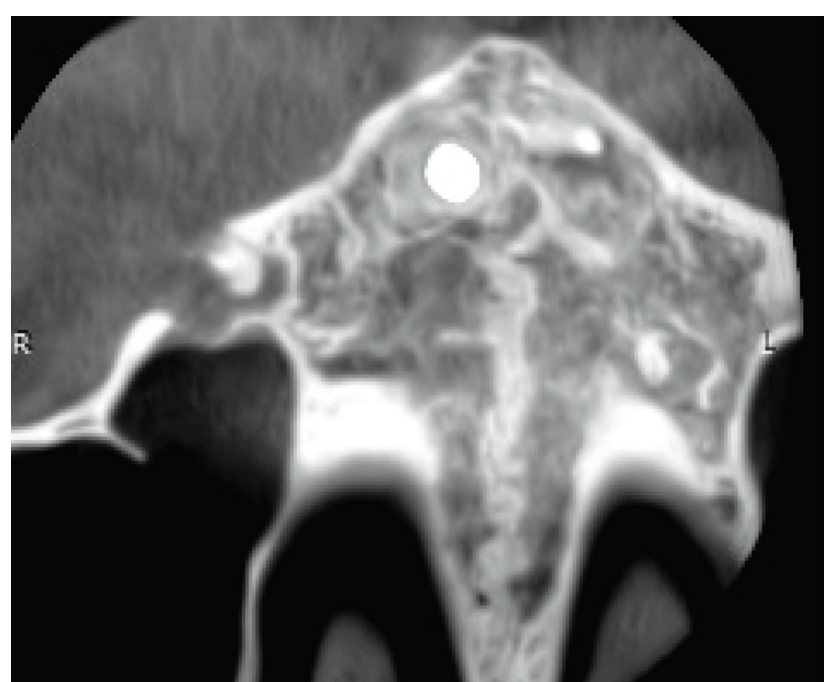

Figure 4. Coronal view of the cyst on tooth 13.
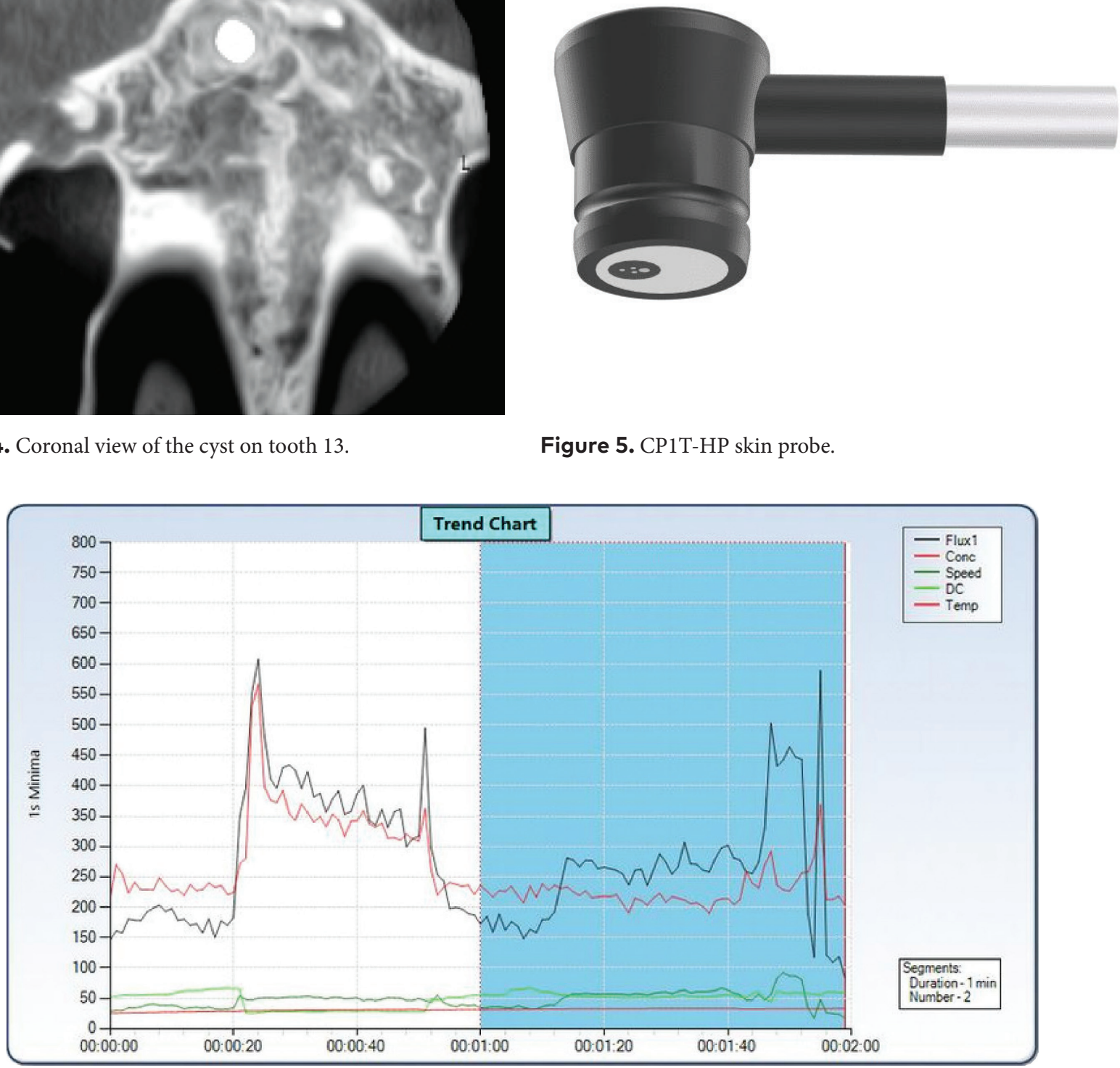

Figure 6. Periapical X-ray of tooth 13 after the nonsurgical root canal treatment.

the exact time of the measurement. Lip was not retracted to avoid twitching. Special goggles provided by the manufacturer filter the wavelength of the laser due to a possible injury of the retina (cataract) and cornea (burn, blurring). The laser effect on the skin was thermal burn. ${ }^{4}$ An LDF monitor (Fig. 1) is a minimally invasive way of reading the frequency of oscillations produced by the doppler frequency shift of the red blood cells in peripheral tissue and translates the frequency to an intensity oscillation.

The CP1T-HP skin probe used for the nonsurgical microcirculation measurement has a fibre separation of $2 \mathrm{~mm}$. It is a high power laser doppler, tissue oxygenation and temperature measurement probe that delivers light at a right angle to the probe cable. The probe has a height of $12.5 \mathrm{~mm}$ and outside diameter of $8 \mathrm{~mm}$ at the probe tip. The monitor has a maximum power of $20 \mathrm{~mW}$ which is equal to $20 \mathrm{~mJ}$. The test setting was set to $15 \mathrm{~Hz}$ which is equal to $0.3 \mathrm{~W} / \mathrm{cm}^{2}$. Max
Figure 5. CP1T-HP skin probe. 
Table 1. Nonsurgical microcirculation (Flux, CONC, Speed, DC, Temp) of tooth 13 Segment 00:00-01:00. Tooth 23 Segment 01:00 02:00.

\begin{tabular}{llllllllllll}
\hline \multirow{2}{*}{ Segment } & Param & Mean & S. Dev & S. Err & Median & Min & Mas & Sum & Area & Offset & Slope \\
\hline & Flux1 & 294.5 & 114.9 & 14.84 & 312.7 & 145.4 & 608.2 & 17671.1 & 2945.2 & 106.3 & 38.29 \\
& Cone & 295.2 & 73.5 & 9.48 & 280.9 & 213.3 & 566.5 & 17709 & 2951.5 & 181.8 & 23.06 \\
00:00:00-00:01:00 & Speed & 43.5 & 7.8 & 1 & 46.4 & 28.7 & 55.6 & 2612 & 435.3 & 30.5 & 2.64 \\
& DC & 43 & 15 & 1.94 & 47.6 & 25.2 & 665 & 2578.1 & 429.7 & 19 & 4.88 \\
& Temp & 29.5 & 1.7 & 0.22 & 30.1 & 25.4 & 31.6 & 1771.9 & 295.3 & 26.7 & 0.58 \\
\hline & Flux1 & 260.9 & 96.2 & 12.52 & 262.2 & 109.3 & 589.3 & 15394.3 & 2565.7 & 114.6 & 30.28 \\
& Cone & 226.7 & 26.9 & 3.5 & 218.7 & 189.7 & 369 & 13375.7 & 2229.3 & 190.8 & 7.42 \\
00:01:00-00:02:00 & Speed & 52.1 & 15.9 & 2.07 & 56.9 & 17.5 & 92.6 & 3074 & 512.3 & 26.7 & 5.25 \\
& DC & 55.5 & 4.6 & 0.6 & 55 & 44 & 67.3 & 3274 & 545.7 & 48 & 1.55 \\
& Temp & 32.6 & 0.5 & 0.06 & 32.7 & 31.5 & 33.3 & 1926 & 321 & 31.9 & 0.16 \\
\hline
\end{tabular}

energy density for the CP1T-HP probe is $0.00265 \mathrm{~J} / \mathrm{cm}^{2}$. The laser fluence/radiant exposure is $26.5 \mathrm{Jm}^{2}$, spectral exposure is $26.5 \mathrm{Jm}^{2} \times 15 \mathrm{~Hz}=397.5 \mathrm{Jm}^{-2} \cdot \mathrm{Hz}^{-1}$ or spectral exposure in wavelength is $26.5 \mathrm{Jm}^{2} \times 785 \mathrm{~nm}=20.803 \mathrm{Jm}^{3}$.

Endodontic surgery was performed a week later due to the size of the lesion and proximity to the maxillary sinus with the help of LiteTouch ${ }^{T M}$ (Light Instruments, Israel) Erbium-doped Yttrium Aluminium Garnet-Er: YAG laser, 2940 $n m$ wavelength. The treatment protocol was performed in the following order. Local terminal buccal and palatal infiltration anaesthesia with Ubestesin forte (Articaine 4\%/1:100000, $3 M$ ESPE, USA), vasoconstrictor adrenaline. Incision was vertical Eskici type (scalpel size 15), distal to the root of tooth 13. Flap reflection was performed with periosteal elevator. Laser bone widening (ostectomy-non-contact mode; 300 mJ/25 Hz; $7.5 \mathrm{~W}$; 1.3×19 mm tip; water level 8). Lesion curettage (granulation tissue ablation-non-contact mode; 400 $\mathrm{mJ} / 20 \mathrm{~Hz} ; 8 \mathrm{~W} ; 0.8 \times 14 \mathrm{~mm}$ tip; water level 4). Laser root resection (apicoectomy-non-contact mode; $400 \mathrm{~mJ} / 20 \mathrm{~Hz} ; 8$ $W ; 0.8 \times 14 \mathrm{~mm}$ tip; water level 8 ). All laser values were taken from previously published cases. ${ }^{6}$ Ultrasonic retrograde preparation was done with tip E30RD-S (NSK, Japan). The retrograde cavity was obturated with Theracal LC (calcium silicate, Bisco Dental, USA) and photopolymerized with Bluedent Express light curing lamp in hyper mode, 410-490 $\mathrm{nm}$ wavelength range, $3500 \mathrm{~mW} / \mathrm{cm}^{2}$ (BGLight, Plovdiv, Bulgaria). After surgery, a graft was placed Novabone (calcium phosphosilicate -(Zimmer Biomet, USA). Flap adaptation and suturing were done with nonresorbable monofilament sutures EvoMat Polypropylene, 5/0, $20 \mathrm{~cm}^{1 / 2}$ Dr Mayer (China). Before graft placement, a new laser doppler flowmetry measurement was performed with VP7BS-HP (Fig. 8) bone probe which does not measure temperature. Probe has a size of $3.3 \mathrm{~mm}$. Max Power Density $0.23 \mathrm{~W} / \mathrm{cm}^{2}$, Max Energy Density $0.02 \mathrm{~J} / \mathrm{cm}^{2}$. Max Power Density is $0.00 \mathrm{~W} / \mathrm{cm}^{2}$ or a peak power density of $0.03 \mathrm{~W} / \mathrm{cm}^{2}$ at $0.5 \mathrm{~s}$ and $15 \mathrm{~Hz}$. The probe was placed directly inside the cystic cavity touching bone for 2 minutes (Fig. 9). The graphical and numerical representation of the cystic cavity readings are shown in Fig.
10 and Table 2. The peaks in Fig. 10 are artefacts of Flux and CONC of erythrocytes readings which are represented by black and light red lines and the Min and Max values in Table 2. ${ }^{6,7}$

Table 2 shows low values of flux, speed and direct current but increased values of CONC. After endodontic surgery, the

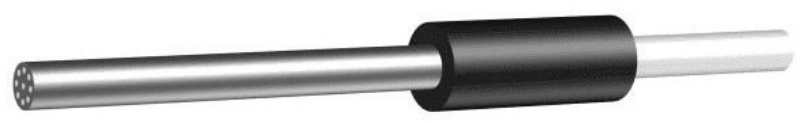

Figure 8. VP7BS-HP bone probe.

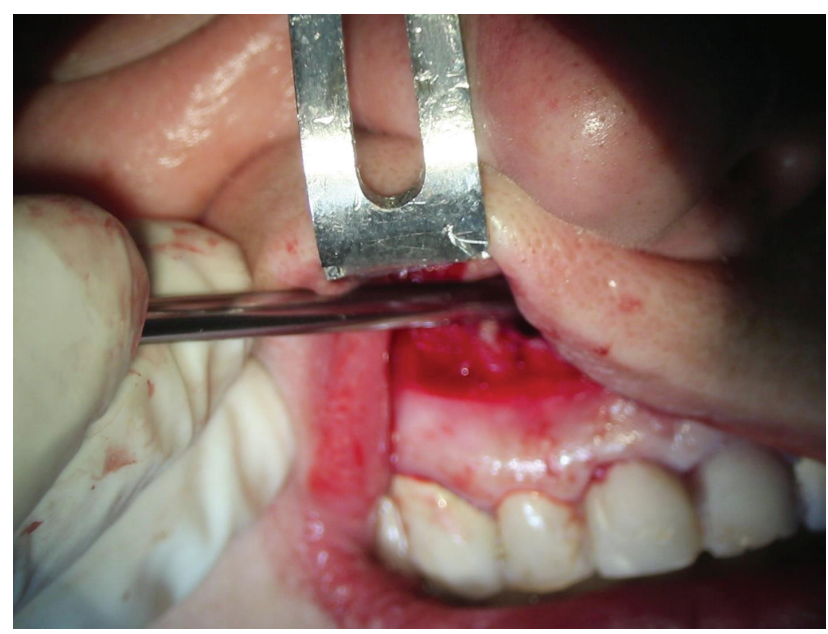

Figure 9. Cystic intraoperative microcirculation measurement with VP7BS-HP bone probe after endodontic surgery with Er: YAG laser. 


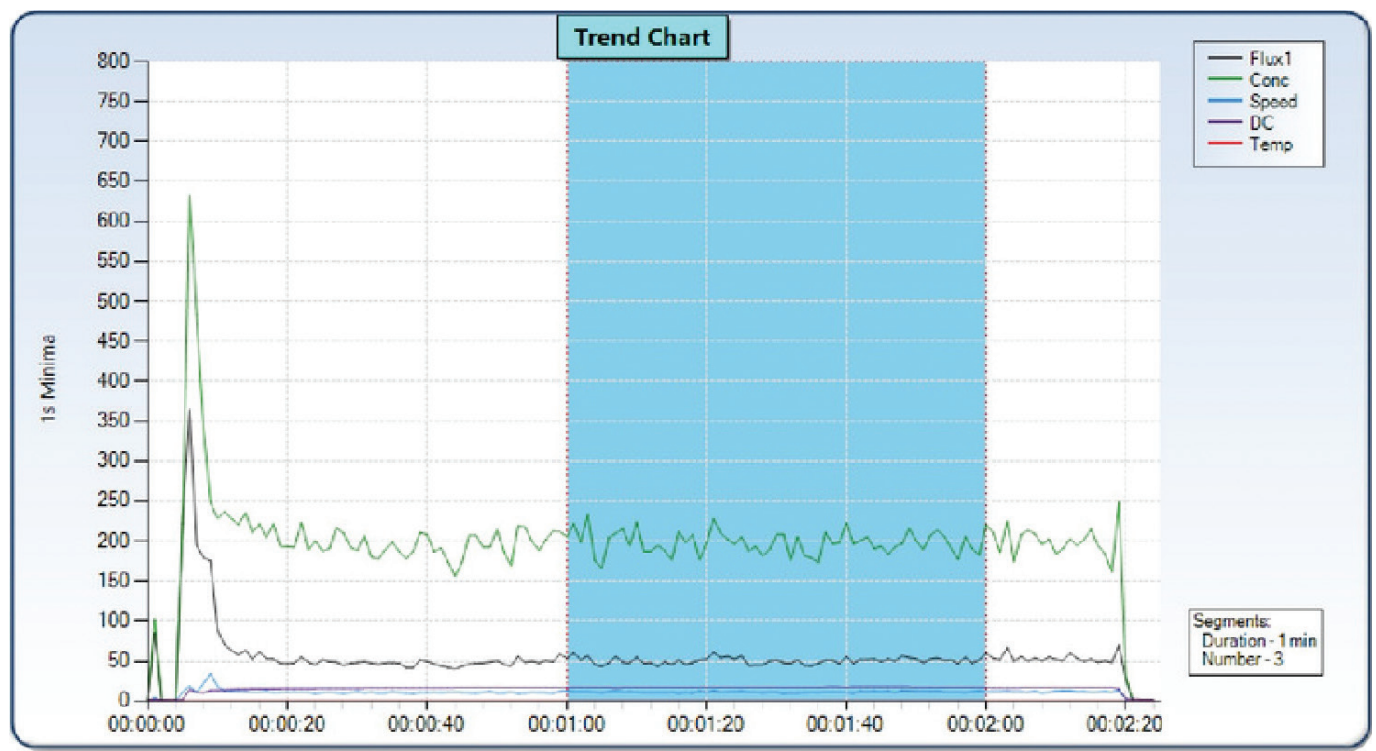

Figure 10. Microcirculaton (Flux, CONC, Speed, DC) of the cystic cavity of tooth 13 after endodontic surgery with Er: YAG laser.

Table 2. Microcirculation (Flux, CONC, Speed, DC) of the cystic cavity of tooth 13 from Segment 00:01:00 to 02:00 minutes after endodontic surgery with Er: YAG laser

\begin{tabular}{llllllllllll}
\hline Segment & Param & Mean & S. Dev & S. Err & Median & Min & Max & Sum & Area & Offset & Slope \\
\hline & Flux1 & 63 & 12.2 & 0.25 & 60.4 & 39.8 & 136.8 & 151362.7 & 3784.1 & 64.4 & -0.05 \\
& Conc & 244.3 & 29 & 0.59 & 242.6 & 155.8 & 372.4 & 586544.3 & 14663.6 & 242.2 & 0.07 \\
00:00:00-00:01:00 & Speed & 13.3 & 2 & 0.04 & 13 & 9.8 & 27.3 & 31862.4 & 796.6 & 13.6 & -0.01 \\
& DC & 16.4 & 0.7 & 0.01 & 16.6 & 14.3 & 17.1 & 39417 & 985.4 & 15.4 & 0.03 \\
& Temp & 0 & 0 & 0 & 0 & 0 & 0 & 0 & 0 & 0 & 0 \\
\hline & Flux1 & 65.1 & 10.7 & 0.22 & 63.5 & 43.1 & 135.2 & 156405.9 & 3910.1 & 61.6 & 0.12 \\
00:01:00-00:02:00 & Conc & 245.3 & 28.8 & 0.59 & 244.3 & 173 & 425.2 & 589305.8 & 14732.6 & 245.2 & 0 \\
& Speed & 13.7 & 1.7 & 0.03 & 13.5 & 9.9 & 24.5 & 32834.6 & 820.9 & 13 & 0.02 \\
& DC & 17 & 0.2 & 0 & 17 & 16.6 & 17.5 & 40867 & 1021.7 & 17.1 & 0 \\
& Temp & 0 & 0 & 0 & 0 & 0 & 0 & 0 & 0 & 0 & 0 \\
\hline
\end{tabular}

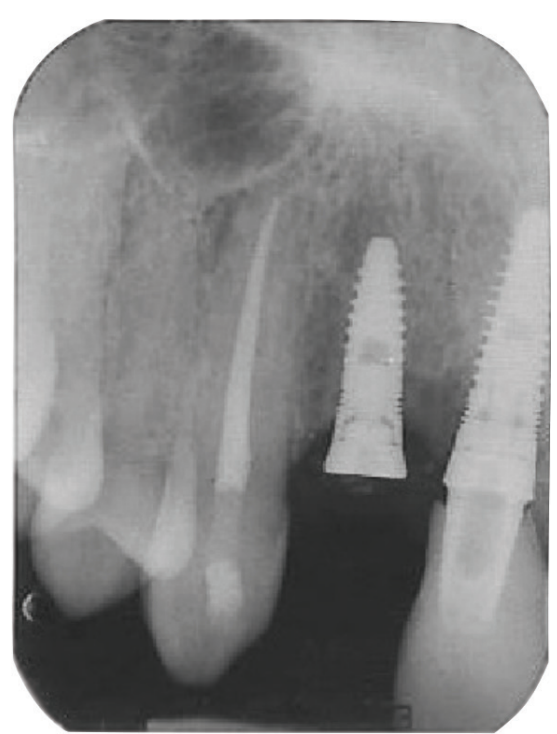

Figure 11. Tooth 13 after endodontic surgery with Er: YAG laser. lesion was confirmed histologically to be a radicular cyst. It healed uneventfully and is under a follow-up period with periapical X-rays (Fig. 11).

\section{DISCUSSION}

A laser doppler flowmeter (Fig. 1) is a minimally invasive way of reading the frequency of the oscillation produced by the Doppler frequency shift of the red blood cells in peripheral tissue and it translates the frequency to an intensity oscillation. The perfusion/flux output is equal to the concentration (number) of the red blood cells times their velocity in a given time which determines circulation. The setting of $15 \mathrm{~Hz}$ detects erythrocytes which move at a maximum speed of $6 \mathrm{~mm} / \mathrm{s}$. The fibre-optic probe usually with one multimode fibre delivers the laser light, often from a semiconductor laser diode, to the tissue, and another mul- 
timode fibre detects the back-scattered photons which are sent to an analyzer-recorder. It is a one-point measurement method which records the integrated perfusion in a sampling volume in real-time. The measurement depth and sampling volume depend on the wavelength and the fiber separation used.

The laser doppler flowmeter has the following parameters. Laser Safety Classification: Class 3R; Output power $20 \mathrm{~mW}$ max; the high power gives a better signal-to-noise ratio in human subjects which is unsatisfactory with lower energy systems. ${ }^{7,8}$ Wavelength is $785 \mathrm{~nm} \pm 10 \mathrm{~nm}$; Angular spread of laser light from probe tip $26^{\circ}$. It measures Flux (perfusion): Range: 0-1000 PU. CONC (concentration of erythrocytes): Range: 0-1000 Arbitrary Units (AU). Direct current velocity DC: Range: $0-1000 \mathrm{AU}$ and Speed. Temperature measurement: Range $5-50^{\circ} \mathrm{C}$. Signal processing: Bandwidth: high pass $20 \mathrm{~Hz}$; Low pass selectable $3 \mathrm{KHz}, 15$ $\mathrm{KHz}, 22 \mathrm{KHz}$; Output time constants: 0.1 s, 0.5 s, 1.0 s, 3.0 $\mathrm{s}$, and unfiltered; Automatic gain control and zeroing. It can be used with different tissue or bone probes.

The infrared light, wavelength of $785 \mathrm{~nm}$ has been found to penetrate deeper into the tissues than smaller wavelengths like green or red. The apparatus can allegedly penetrate $1-13 \mathrm{~mm}$ of non-pigmented tissue. ${ }^{9-11}$ The readings on teeth 13, 23 before surgical treatment over the gum show very high values of Flux, CONC which may be attributed to either artifacts due to hand movement, patient movement, improper placement or too much pressure. These values are defined by calibration against a standard reference of polystyrene micro-spheres, as provided by the manufacturer. The probe was hand held in place which may give some artefacts and changes in flux. The peaks in Figs 6, 10 (vertical axis) are for Flux and CONC (Tables 1, 2 Max column) and usually show patient, hand movement or detachment of the probe at any given moment during the measurement. The perfusion chart should look like electrocardiogram and be consistent with heart pulsations and pulse. More than 1 minute measurement raises the tissue temperature but does not significantly affect the readings (Table 2). Hand-held probes may not affect results so much compared to stents ${ }^{12}$ but others find opposing results and higher reproducibility with stents. ${ }^{13}$ Flux values may come from neighbouring areas as well, like lip - higher values due to muscle twitching after retraction or free and attached gingiva due to marginal periodontitis. ${ }^{10,11}$ It has been proven that gingivitis increases blood flow due to blood stasis in tissues. ${ }^{3}$

The surgical test measurement from inside the cystic cavity shows very low values of flux which may be due to the detrimental effect of the lesion over bone microcirculation or application of local anaesthesia with adrenaline. ${ }^{7,8}$ Cysts are lined with epithelium and grow over time due to increased pressure over bone walls which decreases perfusion. ${ }^{14,15}$ Granulomas, on the other hand, should show increased perfusion due to the increased stasis and abundance of differentiated blood vessels. ${ }^{3}$

Tissue perfusion before and after treatment may be a good predictive factor for healing. It could evaluate different treatment methods as well as lesion type and effect over bone perfusion. ${ }^{9,10}$

As far as we know this is the first time a high power laser Doppler flowmeter has been used to evaluate the perfusion of a periapical lesion before nonsurgical and after surgical endodontic treatment performed with Er: YAG laser. So far this method has been used for soft tissue evaluation and during surgery for femoral head assessment. This method can be used to evaluate different treatment protocols, their effect over bone microcirculation, thus predicting their future healing and prognosis. It can be used for diagnosis of periapical lesions and their activity.

\section{REFERENCES}

1. Narayanan L, Vaishnavi C. Endodontic microbiology. J Conserv Dent 2010;13(4):233.

2. Lin LM, Ricucci D, Kahler B. Central bringing excellence in open access radicular cysts. Review. Radicular Cysts Review. JSM Dent Surg 2017; 2 .

3. Firkova E, Bouka M. Laser doppler flowmetry in the evaluation of periodontal health and disease. J IMAB 2019; 25(3):2599-602.

4. Nair NP. New perspectives on radicular cyst: do they heal? Int Endod J 1998; (31):155-60.

5. Clough G, Chipperfield A, Byrne C, et al. Evaluation of a new high power, wide separation laser doppler probe: potential measurement of deeper tissue blood flow. Microvasc Res 2009;78(2):155-61.

6. Tomov GT, Turkkan MS. Apicectomy of an endodontically compromised central incisor. Laser 2019;1(1):10-2.

7. Bøgehøj M, Emmeluth C, Overgaard S. Blood flow and microdialysis in the human femoral head. Acta Orthop 2007;78(1):56-62.

8. Nötzli HP, Siebenrock KA, Hempfing A, et al. Perfusion of the femoral head during surgical dislocation of the hip. Monitoring by laser Doppler flowmetry. J Bone Joint Surg Br 2002 ;84(2):300-4.

9. Jafarzadeh H. Laser doppler flowmetry in endodontics: a review. Int Endo J 2009; 42(6):476-90.

10. Orekhova LY, Barmasheva AA. Doppler flowmetry as a tool of predictive, preventive and personalised dentistry. EPMA J. 2013;4(1):21.

11. Stefanova V, Manchorova N, Georgieva D, et al. A laser doppler flowmetry for measuring the pulp blood perfusion in teeth with postoperative sensitivity - a case report. J IMAB 2016;22(4):1383-4.

12. Hoke JA, Burkes EJ, White JT, et al. Blood-flow mapping of oral tissues by laser Doppler flowmetry. Int J Oral Maxillofac Surg 1994; 23(5):312-5.

13. Hinrichs JE, LaBelle LL, Aeppli D. An evaluation of laser doppler readings obtained from human gingival sulci. J Periodontol 1995;66(3):171-6.

14. Kouadio AA, Jordana F, Koffi NJ, et al. The use of laser Doppler flowmetry to evaluate oral soft tissue blood flow in humans: A review. Arch Oral Biol 2018; 86:58-71.

15. Kim S, Kratchman S. Modern endodontic surgery concepts and practice: a review. J Endod 2006;32(7):601-23. 


\title{
Лазерная допплеровская оценка микроциркуляции при апикальном периодонтите до и во время хирургического лазерного лечения
}

\author{
Богдан Крастев, Иван Филипов \\ Кафедра оперативной стоматологии и эндодонтии, Факультет дентальной медицинь, Медицинский университет - Пловдив, Пловдив, \\ Болгария
}

Адрес для корреспонденции: Богдан Крастев Кафедра оперативной стоматологии и эндодонтии, Факультет дентальной медицины, Медицинский университет - Пловдив, бул. „Христо Ботев“ № 3, 4000 Пловдив, Болгария; E-mail: drbkrastev@gmail.com; Tel.: +359 897988845

Дата получения: 10 ноября 2019 Дата приемки: 11 февраля $2020 \bullet$ Дата публикации: 30 сентября 2020

Образец цитирования: Krastev B, Filipov I. Laser Doppler assessment of microcirculation of apical periodontitis before nonsurgical and during surgical laser treatment. Folia Med (Plovdiv) 2020;62(3):619-25. doi: 10.3897/folmed.62.e48340.

\begin{abstract}
Резюме
Введение: Лазерная допплеровская флоуметрия является неинвазивным методом измерения микроциркуляторного кровотока в тканях. Мы использовали лазерную доплеровскую флоуметрию Moor VMS-LDF1-HР и зонд CР1T-HР в сочетании с программным обеспечением Moor VMS-PC для оценки состояния периапикального поражения (кисты) перед безоперационным эндодонтическим лечением биокерамикой (Well Root SP ${ }^{\text {мx}}$ ) и сравнили их со здоровым жизненно важным зубом того же типа без периапикальных поражений. Костная фистула кисты была позже исследована с помощью Moor VMSLDF1-HP и зонда VP7BS-HP во время периапикальной операции после удаления кисты с помощью Er: YAG-лазера Lite Touch ${ }^{\circledR}$ (Sineron, Израиль) и ретроградной закупорки с помощью TheraCal LC ${ }^{\oplus}$. Биокерамический костный трансплантат затем поместили на место кисты. Насколько нам известно, это первый случай, когда лазерный допплер использовался во время периапикальной хирургии для оценки перфузии тканей. Тип поражения был подтверждён гистологическим исследованием после операции.
\end{abstract}

Цель: Оценить перфузию тканей периапикального очага перед нехирургическим лечением и во время хирургического эндодонтического лечения лазером Er: YAG с использованием лазерной допплеровской флоуметрии.

Результаты: Лазерная допплеровская флоуметрия показывает, что кистозный зуб имеет уменьшённый кровоток, пониженную концентрацию, постоянный кровоток, скорость и более низкую температуру по сравнению со здоровым зубом того же типа. Во время периапикальной хирургии лазерная оценка кровотока хирургической фистулы имеет различные значения для кровотока, скорости, прямого кровотока, концентрации и температуры, что может быть связано с механической травмой, адреналином под местной анестезией или лазерным распространением в тканях.

Заключение: Лазерная допплеровская флоуметрия является доступным методом оценки ткани до, во время и после лечения. Это позволяет нам отслеживать заживление и патологическую динамику изменений в микроциркуляции тканей, а также оценивать и сравнивать различные методы и материалы для лечения апикального периодонтита.

\section{Ключевые слова}

киста, Er: YAG, лазерная доплеровская флоуметрия, лазер, перфузия 